OPEN ACCESS

Citation: Gallo L. (2020) Sempervivum guillemotii Lamotte (Crassulaceae), a rediscovered houseleek of the French-Italian Alps. Webbia. Journal of Plant Taxonomy and Geography 75(1): 69-76. doi: 10.36253/jopt-7940

Received: November 30, 2019

Accepted: January 28, 2020

Published: June 30, 2020

Copyright: (c) 2020 Gallo L. . This is an open access, peer-reviewed article published by Firenze University Press (http://www.fupress.com/webbia) and distributed under the terms of the Creative Commons Attribution License, which permits unrestricted use, distribution, and reproduction in any medium, provided the original author and source are credited.

Data Availability Statement: All relevant data are within the paper and its Supporting Information files.

Competing Interests: The Author(s) declare(s) no conflict of interest.

Editor: Riccardo M. Baldini, University of Florence, Italy

\section{Sempervivum guillemotii Lamotte (Crassulaceae), a rediscovered houseleek of the French-Italian Alps}

\author{
LORENZO GALLO \\ Strada Val San Martino sup. 194, 10131, Torino, Italy \\ E-mail: lorenzogallo1959@hotmail.it
}

\begin{abstract}
Sempervivum guillemotii (Crassulaceae) was discovered and described by Martial Lamotte in the French Alps, but apart from Rouy \& Camus, it was never cited in the French floras. Burnat later rediscovered it, but unaware of Lamotte's name, he published it under the name S. adenotrichum; this name, too, did not find its way into the floras until the recent Flora Gallica. The author rehabilitates this name and designates a neotype for the name $S$. guillemotii and a lectotype for its synonym S. adenotrichum.
\end{abstract}

Keywords: Crassulaceae, Sempervivum adenotrichum, S. guillemotii, Western Alps.

\section{INTRODUCTION}

The genus Sempervivum L. (Crassulaceae) has been the subject of a great many studies, particularly in the nineteenth century, and a lot of taxa have been described especially in Austria, France, and Switzerland. Today there are hundreds of names, most of which are treated as synonyms; of these, very few being present in the major continental Floras. One of the most prolific and important authors of the period was Martial Lamotte (1820-1883), a French botanist who discovered and published a great many new species (Dayrat 2003). These include Sempervivum guillemotii Lamotte, the object of this study, which he described in detail. In particular, he highlighted its petal position at anthesis, its glabrous (or almost glabrous) stamens, a rare feature in the Sempervivum genus, and, rosette leaves which are glandular on the surface and have long $(1 \mathrm{~mm})$ cilia on their leaf margins (Lamotte 1856). Since its publication, S. guillemotii has been very rarely mentioned in the Euro-Mediterranean floras contexts and in France. Rouy \& Camus (1901) treated this taxon simply as a 'forme' of S. arvernense Lecoq \& Lamotte and, as a result, it was ignored by all subsequent Floras. Burnat (1906) later rediscovered it, but he was unaware of the earlier name published by Lamotte and published it as $S$. adenotrichum Burnat. No reference is made of this name in any major French Flora until Kerguelen (1999), who cites it as a synonym of S. tectorum L. subsp. arvernense (Lecoq \& Lamotte) Bellia \& De Andrade, 
and Tison and Foucault (2014), who consider it a '[...] lignée fixée de $S$. xschottii C.B. Lehm. \& Schnittsp. (cf. Hybrides) [...]' and later 'une espèce hybridogène'. In Italy, despite its widespread presence in the Piedmontese Cottian Alps, it does not appear in any Flora (Pignatti 1982; Gallo 2005; Gallo 2017; cf. also Gallo 2019). Likewise, S. guillemotii is not mentioned in Euro-Mediterranean contexts, such as the Euro+Med PlantBase (2006). Recently, the Catalogue of Life (Roskov et al. 2018), cites it as a synonym of $S$. tectorum $\mathrm{L}$. In the specialist literature, Correvon (1924) accepted the species, but its description lacks morphological diagnostic details. Praeger (1932) placed this taxon as a synonym of $S$. tectorum, while 't Hart et al. (2003) treated it as a synonym of $S$. tectorum var. tectorum.

The nomenclatural and taxonomic data related to this forgotten taxon are therefore very scarce and this study aims to explain the problem and restore the proper name for this taxon. To give stability and certainty to the name application, typifications of the name $S$. guillemotii and its synonym $S$. adenotrichum are provided.

\section{MATERIAL AND METHODS}

The morphological and biological characteristic of S. guillemotii and similar taxa were studied in the field (French and Italian Western Alps) and especially the type material of S. guillemotii and S. adenotrichum also in several herbaria (FI, G, GAP, LY, P and TO). Taxonomical and historical data were also investigated in the French and Italian literature. A comparison through statistical analysis (Anderson-Darling Normality test and paired t-test) of the altitudes of $S$. guillemotii and $S$. montanum L. subsp. burnatii (Wettst. ex Burnat) Hayek in Hegi, was performed with MaxStat. The distribution map was created with SimpleMappr. The distribution area will also be defined by integrating the distributional data used by Polidori et al. (2018), the exsiccata traced at G-BU and P, and the author's unpublished data. An analytical key, including morphologically similar taxa distributed in the same area is also proposed.

\section{Taxonomy}

In his protologue, Lamotte (1856) named the new species after M. [Monsieur] A. Guillemot (see Etymology), 'qui en a fait la découverte' and who sent the plants upon which the description had been based. It does not appear that this plant has been preserved but it was cultivated only, indeed there are no indications of its possible preservation in Lamotte's herbarium. The Lamotte her- barium is currently preserved at CLF (Dayrat 2003), and in a recent paper reporting the results of a study on the types contained in it, 11 specimens of Sempervivum were listed but no S. guillemotii (Roux 2010). This taxon is also missing from the remaining general herbarium of CLF (Roux in litt.). Likewise, the exsiccata collected by Lamotte are not traceable at FI and G. Indeed, it seems very unlikely that any herbarium specimens exist, since this same author states: 'Malheureusement, je ne puis la faire quant à présent, l'hiver de 1859-60 m’ayant fait périr ce que je possédais de ce Sempervivum sauf quelques petites rosettes qui n'ont pas encore donné de fleurs' (Lamotte 1864). Thus, Lamotte cultivated S. guillemotii for some years (Crépin 1865) but appears not to have prepared a specimen. This lack of original material forces the author to designate a neotype collected in the area where Guillemot gathered his material: the provenance selected is the Lac du Lauzanier, located in the area between Larche and Barcelonnette (Provence-Alpes-Côte d'Azur, France); here the author rediscovered this taxon in 2019.

S. adenotrichum was, on the other hand, described by E. Burnat based on specimens found in two different localities in the French Maritime Alps (Mont Férant and Cima della Fascia). Over his lifetime, Burnat built up a large herbarium kept separately at the Conservatoire de Botanique de Géneve as G-BU. The herbarium consists of more than 200,000 specimens, many of which are from the Maritime Alps (Jeanmonod \& Charpin (2017). Studies aiming to typify names published by Burnat have already been carried out on this herbarium, the most important being Jeanmonod's study (2018). Here the author clarifies the best method with which to typify the names published by Burnat. There is almost always a complete coincidence - with respect to the presence of original materials - between the protologue and his herbarium. In Burnat's herbarium, two syntypes were found, corresponding to the localities listed in the protologue: one of these (Mont Férant, Fig. 2) was chosen as lectotype, because of a label written by J. Briquet (confirmed by D. Jeanmonod, in litt.) in 1903 and displaying the quote 'Sempervivum adenotrichum Burnat et Briquet' (Figure 1B). On the other syntype, from 'Cima della Fascia', a small drawing can be observed depicting two 'Poils glanduleux des feuilles adultes (Figure 1A)', one of the diagnostic features of $S$. guillemotii.

Sempervivum guillemotii Lamotte in Communication. Bull. Soc. bot. France, 3: 457. 1856

Type: France. B. ${ }^{\text {ses }}$ Alp. es. " Env. de Larche. (Le Lauzanier). Rive S. du Lac du Lauzanier. Alt. ${ }^{\text {de }} 2280^{\mathrm{m}}$. Roch- 


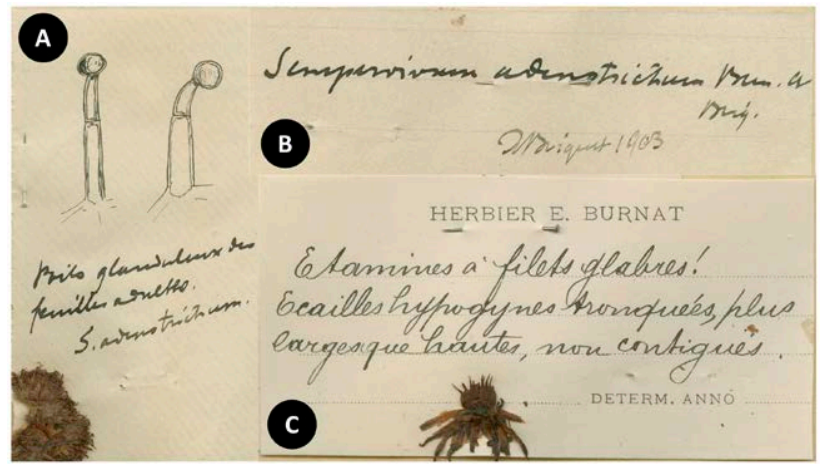

Figure 1. Details of the labels of the syntypes of Sempervivum adenotrichum Burnat. A. Drawing of E. Burnat, showing the glandular cilia on the leaf margins (G00848069). B. Label written by J. Briquet (Lectotype, G00848068). C. Label with morphological notes (Lectotype, G008488068).

ers. 15 Juillet 1949 ». Laurence (Herb. H. Laurence, P00321304, P [digital image at http://mediaphoto.mnhn. fr/media/1441344133347hfUgodcx0ryISleF]). Neotype here designated.

(=) Sempervivum adenotrichum Burnat in Fl. Alpes Marit. 4: 49.1906

Type: France. Mont Férant, a l'W du Mt. Mounier. Rochers. Calcaire. 2000 m, Burnat, Briquet, Cavillier, Verguin et Saint Yves, 22/VII/1902 (G00848068, G-BU [Fig. 2]). Isolectotype G00848068a: Syntype: G00848069 (G-BU). Lectotype here designated.

\section{Etymology}

Dedicated to the French entomologist A. [Antoine] Guillemot (1822-1902) a butterflies specialist (Fournier 2015) See also: https://it.wikipedia.org/wiki/Antoine Barth\%C3\%A9lemy Jean Guillemot).

\section{Description and differentiation from similar taxa}

Rosettes leaves erect or suberect, 30-100 (150) mm diameter. Leaves glandular on both faces, ciliate at the margins with glandular cilia ( $1 \mathrm{~mm}$ long); green or somewhat glaucous, (8)-10-(15) $\mathrm{mm}$ broad and (25)-30-(50) long, linear or obovate with brown or violet apex. No smell of resin. Inflorescences strong, (12)-20-(30) cm long, glandular; compact not scorpioid. Flowers rounded in the bud and densely glandular. Petals (11)-12-(15), linear, reflexed toward the apex (decumbent) or twisted with a hooked tip, light or dark pink, with a green central line and violet spots of varying size; (10-) 12-14 (-15) $\mathrm{x}$ (1-) 1,5-2,5 (-4) $\mathrm{mm}$. Carpels erect, green, glandular at least on the ventral side, but often throughout with

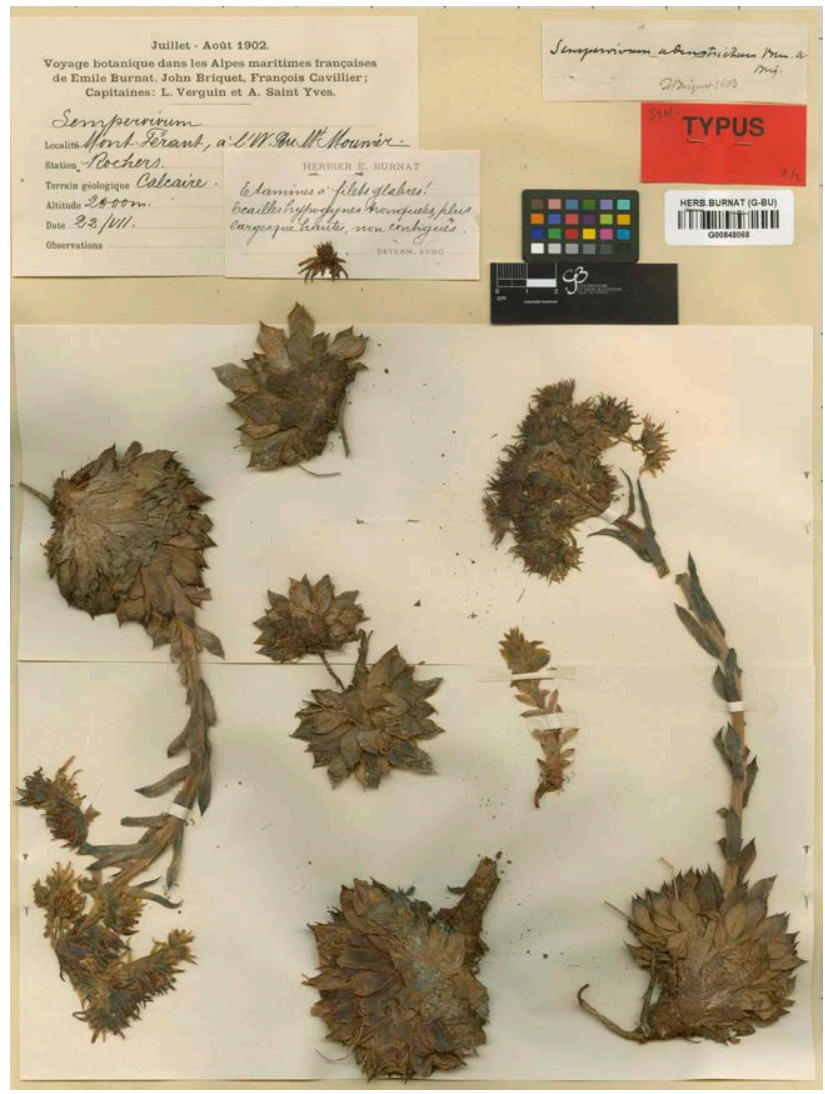

Figure 2. Lectotype of Sempervivum adenotrichum Burnat (G00848068, G-BU (Photo: Conservatoire Botanique de Géneve, G-BU).

transparent or red (Vallée de la Tinée, France) glandules. Styles red-violet erect or somewhat outwards. Filaments violet, glabrous at the base or with 1-2 glandular hairs. Anthers (before dehiscence) violet sometimes bronze, with or without mucro. Nectary scales quadrangular, transparent or slightly permeated with yellow, apex retuse or flat.

S. guillemotii coexists, with S. arachnoideum L., S. tectorum, S. montanum subsp. burnatii Wettst. ex Hayek and a hybrid of the last two $(=S$. xschottii C.B. Lehm. \& Schnittsp., according to a part of the current literature e.g. Praeger 1932, Jacobsen 1977, Gallo 2019) and can easily be confused with these. The characteristic presence of glandular hairs on the leaf faces and cilia on the leaf margins (often glandular) excludes the two putative parents. Sempervivum guillemotii can be distinguished from the hybrid by means of the filaments: glabrous or (rarely) with 1-2 glandular hairs in S. guillemotii but very glandular in the hybrid (see the analytical key). The guidance provided by Lamotte (1856) on the glandulosity of the filaments "Etamines [...] légèrement hispidules- 
glanduleux à la base [...]" is very unclear but, from what was seen in the field by the author can be quantified as not more than 1-2 glandular hairs per filament. Furthemore, the frequency of occurrence in the wild varies significantly: in agreement with Polidori et al. (2018), $S$. tectorum and $S$. montanum hybrids occurs as scattered specimens, usually near their parents (cf. Gallo 2001). S. guillemotii forms, quite often large populations, sometimes with giant clumps of rosettes some of which attain considerable size, and often in the absence of at least one of the two putative hybrid parents.

Analytical key to distinguish S. guillemotii from other similar taxa present in the area studied

1. Leaves glandular on the margins and scented of resin, petals violet (rarely pink or in part yellow), whitish the margins ........................................... . montanum subsp. burnatii

Leaves with cilia at the margins, no smell, petals never violet

2. Leaves glabrous throughout, petals white-pink, $10-11 \mathrm{~mm}$ long.

S. tectorum

Leaves glandular on both faces, petals dark rose or redviolet, petals longer than $S$. tectorum 3

3. Filaments very glandular, rare and isolated plants S. $\times$ schottii

Filaments glabrous or (rarely) with 1-2 glandular hairs, populations with many plants S. guillemotii

The analytical key must be considered a rough tool to identify taxa with similar morphological features growing in the Maritime-Cottian Alps. However, it must be borne in mind that, hybridization occurs very easily in the Sempervivum genus and is well known (Loret 1858; Baker 1879; Vaccari 1905; Praeger 1932; Favarger et al. 1968; Favarger 1969; Favarger; 1971; Rowley 1982; Gallo 2001; 't Hart et al., 2003; Gallo 2012), and hybrids are often not easy to distinguish from its parents. During the research in the field, I found plants that could be interpreted as S. guillemotii hybrids with other taxa such as $S$. montanum subsp. burnatii or also $S$. arachnoideum several times (see also Polidori et al. 2018), but to date it has not been possible to identify them unequivocally. Further study in this regard is already underway.

\section{Habitat}

S. guillemotii occurs in pastures among rocks and debris, where vegetation is absent or very scarce, in full sun, more rarely in tall grass. In one case it was found

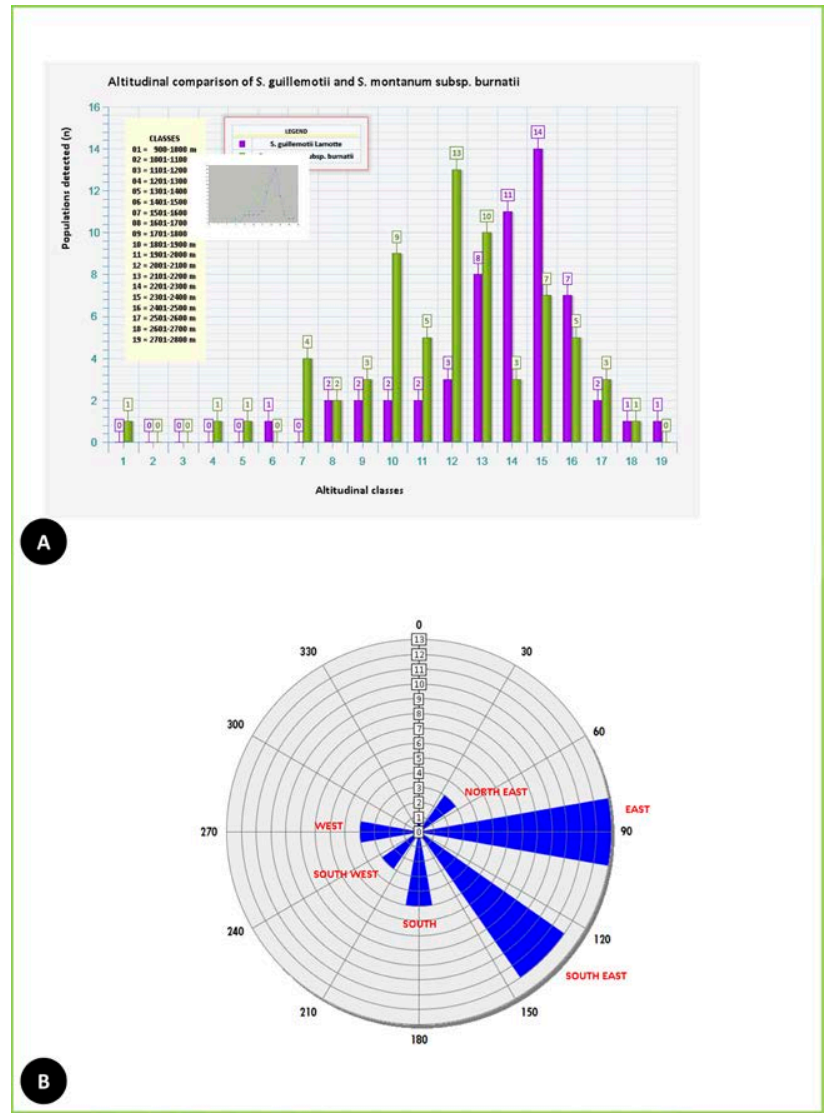

Figure 3. Ecological data related to Sempervivum guillemotii. A. Comparison of the altitudes of S. guillemotii Lamotte and S. montanum L. subsp. burnatii Wettst. ex Hayek. B. Exposure of S. guillemotii as found in the field.

on the top of a stone wall but had probably been cultivated there. Its habitat is often sloping and south or east facing (Figure 3B) (see also Polidori et al. 2018). Perhaps, S. guillemotii is a somewhat sensitive to cold winters, and probably also to long-lasting snow. This species has been found from $1400 \mathrm{~m}$, in Vallée de la Tinée (France), to $2714 \mathrm{~m}$, in Valle Maira. Figure 3A gives a comparison between the altitudes - as seen during field trips - between S. guillemotii and S. montanum subsp. burnatii, with which it often coexists in the same area. S. guillemotii is frequent especially between altitudes of 2100 and 2500 metres (classes 13-16) while it is rare at both lower and higher altitudes (classes). The distribution of the two frequencies, evaluated with the Anderson-Darling Normality test, is normal. Conversely, no significative difference appears between the altitudes reported for the two species: the paired t-test was not positive $(\mathrm{T}=0.681$, $\mathrm{p}$-value $=0.5047, \mathrm{P}<0.05$, significance level 95\%), although S. montanum subsp. burnatii was detected at a lower altitude and presented a 'distributive 


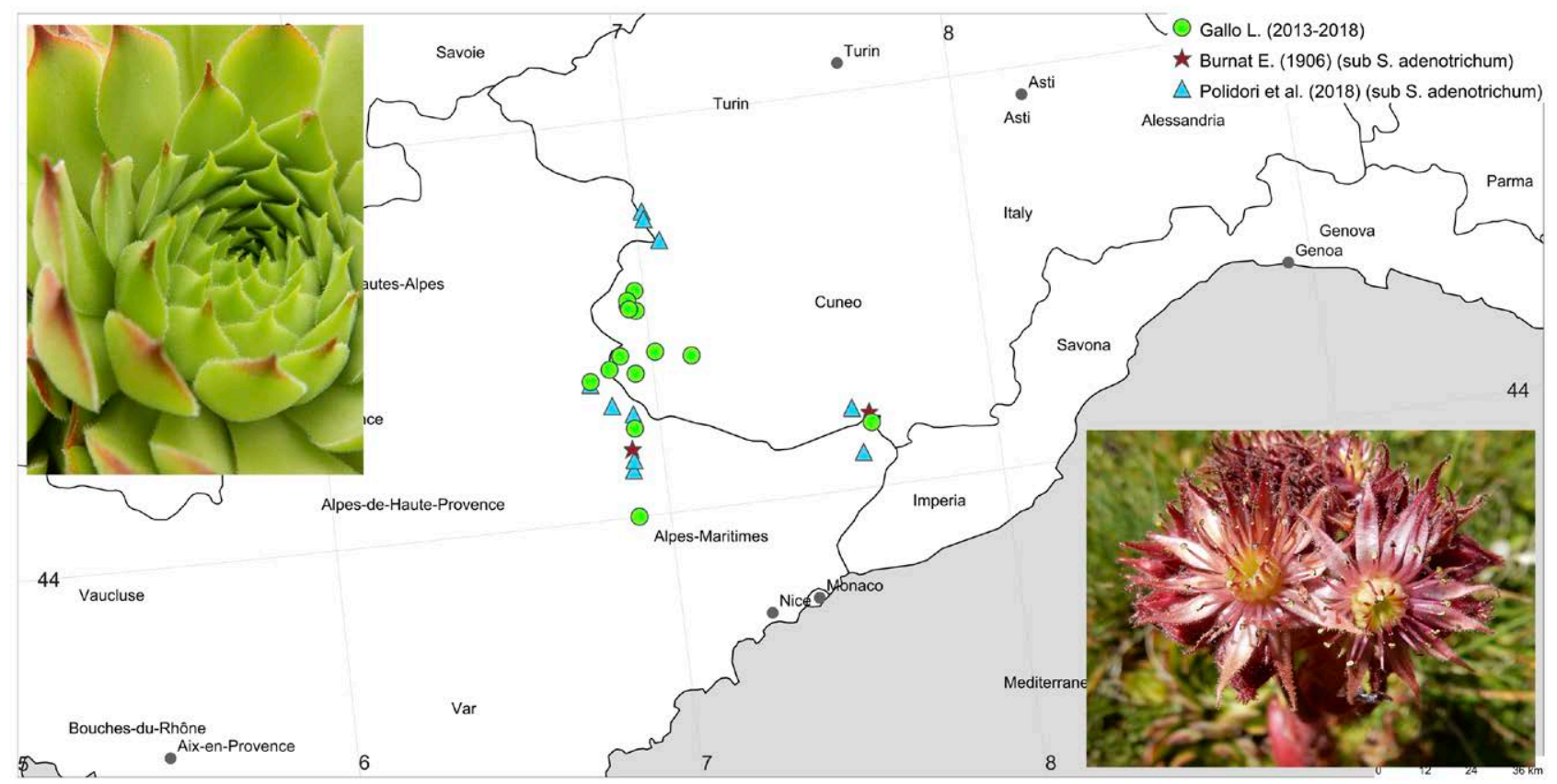

Figure 4. Distribution area of Sempervivum guillemotii Lamotte (incl. S. adenotrichum Burnat).

queue' which was wider to the left. Polidori et al. (2018) also report an empirical study evaluating the $\mathrm{pH}$ value of the ground at the level of the roots in the French Maritime Alps, obtaining a range of values, roughly 5 to 7 ; these data however, appear inconsistent with what Burnat writes (1906: 49): 'Sur les lieux mêmes nous avons noté que le soil étatit calcaire dans les deux cas [...]'.

\section{Distribution area}

S. guillemotii is currently considered to be endemic in the Western Alps (Figure 4), but possible disjunct populations discovered in non-Alpine French areas, currently under investigation, have complicated the issue concerning its origin. In France, where the species was discovered, it is mainly to be found in the Maritime Alps (Polidori et al. 2018) but some northerly populations have been found in the Queyras (Hautes-Alpes); the author found it also in Ubaye, Vallée de la Tinée, Val Roya and Lauzanier. In Italy, the first published report is from the neighbourhood of Limone Piemonte (Val Vermenagna) (cf. Bellone in Polidori et al. 2018) but this identity was already ascertained in 2013 (see Additional specimens examined) although it had been gathered many years before (see appendix 1). Its current Italian distribution includes the Cottian Alps (Val Grana, Val Maira and Val Varaita) and Maritime Alps (Val Stura). See the appendix 1 for a list of living specimens studied.

\section{Origins}

The origins of S. guillemotii are obscure, a genetic mutation or an ancient hybridization can be supposed. Burnat (1906) (sub S. adenotrichum) assumes that the parents were $S$. tectorum and $S$. montanum, but a lack of other taxa in the area made it impossible for him to verify this hypothesis. Tison and Foucault (2014) (sub S. adenotrichum) treat it as a hybrid between $S$. tectorum and S. montanum, found from the Maritime Alps to Valle d'Aosta. These French authors do not distinguish, between S. guillemotii and the casual hybrid (=S. ×schottii), which should be kept distinct, especially because the origin of S. guillemotii might be different from that of S. $\times$ schottii. The hypothesis that it is a successful natural hybrid (or also allopolyploid) is credible whereas it is much more difficult to identify the parents; while S. guillemotii could be a hybrid between taxa belonging to the groups of $S$. tectorum and $S$. montanum, it is not necessarily true that the parents are these two species sensu stricto.

\section{Phenology}

The anthesis is in July, the pollination is entomophilous as is usual in the genus Sempervivum; the flowering and the consequent production of seeds is erratic since the formation of inflorescences, in many of the studied populations, lacks in some years. 


\section{Iconography}

Polidori et al. (2018); Gallo (2019).

\section{Additional specimens examined}

ITALY: Piedmont. Cuneo, Valle Maira, Vallone di Unerzio, From Prato Ciorliero to Passo Gardetta. $2181 \mathrm{~m}$, W. Grassland among calcareous rocks. 339916N, 4920648E. Gallo, 14/07/2013 [GL-8004/2] (8220/ 11.2018, TO).

\section{ACKNOWLEDGEMENTS}

Special thanks to N. Turland (Bot. Garten and Bot. Museums of Berlin) for his valuable advices during the review process. I'm indebted to C. Roux (UNIVEGE, Clermont Université, Clermont-Ferrand) for informations regarding the specimens of the herbarium CLF and L. Loze (Conservatoire et Jardin botanique de Gèneve) for the pictures of the syntypes of S. adenotrichum stored at G. Thanks to D. Jeanmonod (Conservatoire et Jardin botanique,de Gèneve) for his advices on Briquet's handwriting, G. Baldizzone (Asti) and F. Fournier (SHNAO, Aubière) for informations on A. Guillemot. Finally, an appreciation to F. Estivi (Library - Department of Life Sciences and Systems Biology, Univ. of Turin) for the assistance with the bibliographical research.

\section{REFERENCES}

Baker JG. 1879. A synopsis of the hardy forms of Sempervivum now in cultivation in England. Gard. Chron., $12: 10,38-39,85,107,135-136,166,268-269,428-429$, 650.

Burnat E. 1906. Flore des Alpes Maritimes. 4:1-51, 286287. Genève: H. Georg.

Correvon H. 1924. Les Joubarbes. Burgess Hill: Sempervivum Soc.

Crépin F. 1865. Review. Bull. Soc. Roy. Bot. Belgique 4:60-67.

Dayrat B. 2003. Les botanistes et la flore de France. Paris: Mus. nat. Hist. nat.

Euro+Med (2006-). Euro+Med PlantBase - the information resource for Euro-Mediterranean plant diversity. [accessed 14/11/2019]. Published on the Internet http://ww2.bgbm.org/EuroPlusMed/.

Favarger C. 1969. Le role d'un jardin botanique dans les recherches de cytotaxinomie. Boissiera, 14:99-108.

Favarger C. 1971. Heurs et malheurs d'un jardin expérimental. Bull. Jard. Bot. Natl. Belg., 41:27-41.
Favarger C, Maeder AM, Zesiger F. 1968. Hybrides interspecifiques et intergeneriques chez les Joubarbes. Jahresber. Schweiz. Ges. Vererbungsf. 3/4:18-30.

Fournier G. 2015. Antoine Guillemot entomologiste thiernois; Editions Revoir [Not seen].

Gallo L. 2001. Le Crassulaceae della Valle d'Aosta. Distribuzione, morfologia ed ecologia. Monogr. Mus. Reg. Sci. nat. S. Pierre. 3:264.

Gallo L., Crassulaceae. In: Conti F, Abbate G, Alessandrini A, Blasi C. (Eds.) 2005. Annotated Checklist of the Italian Vascular Flora. Roma: Palombi ed.

Gallo L. 2012. Sempervivum $\times$ luisae Gallo (Crassulaceae) hybr. nov.: endemico dell'Italia centrale. Ann. Mus. Civici-Rovereto, 27:287-296.

Gallo L. 2017. Crassulaceae: 915-950. In: Pignatti et al. Flora d'Italia, $2^{\circ}$ ed. 1 . Bologna: Edagricole.

Gallo L. 2019 ['2018']. Crassulaceae italiane. Aggiornamenti e correzioni alla seconda edizione della Flora d'Italia di Sandro Pignatti e al Portale della Flora d'Italia. Ann. Mus. civ. Rovereto, 34:143-167.

Hart H 't, Bleij B, Zonneveld B. 2003. Sempervivum. In: Eggli U. (Ed.). Illustrated Handbook of Succulent Plants. Crassulaceae:332-349. Berlin: Springer-Verlag.

Jacobsen H. 1977. Lexicon of succulents plants. $2^{\circ}$ ed. Blandford Press, Poole, 682 pp.

Jeanmonod D. 2018. Typification des noms de taxons corses de l'herbier Burnat (G-BU). Candollea, 73:6174.

Jeanmonod D., Charpin A. 2017. L'Herbier Burnat (G-BU). Candollea, 72:143-153.

Kerguelen M. 1999. Index synonymique de la flore de France. [accessed 14/11/2019]. https://www2.dijon. inra.fr/flore-france/sea-sep.htm.

Lamotte M. 1856. Communication. Bull. Soc. Bot. Fr., 3:457-458.

Lamotte M. 1864. Etudes sur le genre Sempervivum. Mém. Acad. Sci. Clermont-Ferrand, 6:257-311.

Loret H. 1858. Des hybrides et spécialement de l'hybridation mutuelle de deux Sempervivum. Bull. Soc. Bot. France, 5:146-151.

Pignatti S. 1982. Flora d'Italia, 1: 488-504. Bologna: Edagricole.

Polidori J-L Arnoux J-C, Bellone GT. 2018. Sempervivum adenotrichum Burnat ou Joubarbe à poils glanduleux, taxon méconnu des Alpes occidentales, observé dans les Alpes maritimes. Bull. Naturalistes Alpes-Maritimes [Riviera Scientifique], 102:3-32.

Praeger RL. 1932. An Account of the Sempervivum group. The Royal Horticultural Society. Colchester, London \& Eton: The Ballantyne Press.

Roskov Y, Abucay L, Orrell T, Nicolson D, Bailly N, Kirk PM, Bourgoin T, DeWalt RE, Decock W, De Wever 
A, Nieukerken E van, Zarucchi J, Penev L (Eds.). 2018. Species 2000 \& ITIS Catalogue of Life, 2018 Annual Checklist. [accessed 14/11/2019]. www.catalogueoflife.org/annual-checklist/2018. Species 2000: Naturalis, Leiden, the Netherlands. ISSN 2405-884X.

Roux C. 2010. La conservation et le recensement des types nomenclaturaux du Massif central dans les herbiers de M. Lamotte et de H. Lecoq. Conservation and inventory of nomenclatural types from the French central massiv in the herbaria of M. Lamotte and $\mathrm{H}$. Lecoq:99-104. Actes des Rencontres végétales du Massif central / 28-30 avril 2010.

Rouy G, Camus EG. 1901. Flore de France. 7:126-147. Paris: Les Fils d'E. Deyrolle.

Rowley GD. 1982. Intergeneric hybrids in succulents (conclusion). Natl. Cact. Succ. J., 37:76-80 + 119 .

Tison JM, Foucault B de. 2014. Flora Gallica. Flore de France. Mèze: Biotope Ed.

Vaccari L 1905. Il Sempervivum gaudinii Christ e la sua distribuzione nelle Alpi. Ann. Bot. (Roma), 3:21-41.

\section{APPENDIX 1. LIVING SPECIMENS STUDIED BY THE AUTHOR}

France (P.A.C.A.). Vallon Lauzanier, Lac du Lauzanier towards Pas de Cavale, debris with Sedum alpestre, Daphne sp., Hylotelephium anacampseros, Veratrum album, Adenostyles sp. ecc. 2353 m, E, 0330236 E, $4915588 \mathrm{~N}$ (GL-8437, 8440, 8860, 8861 8864, 8 July 2019). Between Colle della Boaria and Rif. Morgantin, calcareous rocks, 2181, SE (GL-4538). Vallée de la Tinee, Circuit de la Tortisse da le Prà au Lacs de Vens, pasture, 2260 m, 0334656 E, 4909146 N (GL-7408, 10 August 2011). Vallée de la Tinée, between St. Etienne and Auron, in the scrubland with Buxus sempervirens, $1400 \mathrm{~m}$., 0336314 E, 4899070 N (GL-7377, 8 August 2011). Vallée de la Tinée, Auron, hill above the parking among the shrubs, with Juniperus sp. e Lavandula sp., $1691 \mathrm{~m}$, 0334301 E, 4898893 N (GL-7379, 7382, 8 August 2011). Vallée de la Tinée, Col de la Bonette, under the summit, pasture, $2611 \mathrm{~m}$ (0326434 E, 4911160 N (GL-7386, 9 August 2011). Ubaye, Vallone Fouillouse toward Col $\mathrm{du}$ Vallonet, moraine in the valley, pasture with rocks with Vaccinium myrtillus and Dryas octopetala, 2295 m, 0683346 E, 4450245 N (GL-8735, 23-26 July 2018). Italy (Piemonte, Cuneo). Val Maira, between Viviere and Colle Ciarbonet (Baite Rosano), rocks, $2075 \mathrm{~m}$, L. Gallo obs. 31 July 2001. Val Maira. Vallone Traversiera from Madonna delle Grazie to Rif. Carmagnola, pasture 2365 m, 0377252 E, 4932191 N (GL-8107, 10 luglio 2014). Val Maira, Vallone Maurin, Refuge D. Sartore, pasture with rocks, $2444 \mathrm{~m}, 0332569$ E, $4927464 \mathrm{~N}$ (GL-8222, agosto 2014). Val Maira, Vallone Maurin, trail for Colle Bellino from the parking, pasture with rocks near the chalets, $2201 \mathrm{~m}, 0334411 \mathrm{E}, 4933377 \mathrm{~N}$ (GL-8476). Val Maira, Vallone Maurin, trail for Colle Bellino, pasture with rocks, 2248 m, 0334638 E, 4933540 N (GL-8478). Val Maira, Vallone Maurin, trail for Colle Bellino from the parking, pasture with rocks, $2350 \mathrm{~m}, \mathrm{SE}, 0334759 \mathrm{E}$, 4933892 N (GL-8479, 8480). Val Maira, Vallone Maurin, trail for Colle Bellino from the parking, pasture with rocks, $2247 \mathrm{~m}, \mathrm{~S}, 0334445 \mathrm{E}, 4933588 \mathrm{~N}$ (GL-8481). Val Maira, Vallone Maurin, loc. Saretto towards refuge D. Sartore - Fonte Baciasse, pature, 2349 m, E, 0332791 E, 4927489 N (GL-8217, august 2014). Val Maira, Vallone Maurin, loc. Saretto toward refuge D. Sartore - Fonte Baciasse, pasture with rocks, $2192 \mathrm{~m}, 0333198$ E, 4927417 N (GL-8211, 8212, 8213, 8214, august 2014). Val Maira, Vallone Maurin, Between Colle Greguri and Colletto, on the trail near the 'Fortino dei cavalli', pasture with rocks, 2438 m, NW 0335256 E, 4931314 N (GL-6786). Val Maira, Vallone Traversiera, towards Colle di Traversiera, under N. Freide/Aubrage, pasture, $2247 \mathrm{~m}$, SW, 0338410 E, 4931423 N (GL-8199, august 2014). Val Maira, Vallone Traversiera, towards Colle di Traversiera under N. Freide/Aubrage, pasture with rocks, 2260 m, E, 0338320 E, $4931479 \mathrm{~N}$ (GL-8193, august 2014). Val Maira, Vallone Traversiera, from Madonna delle Grazie towards Rif. Carmagnola, 2458 m, 0336919 E, 4933219 N (GL-8572, July 2016). Val Maira, Vallone Traversiera, from Madonna delle Grazie towards Rif. Carmagnola, 2507 m, 337056 E, 4933777 N (GL-8573, July 2016). Val Maira, Vallone Traversiera, from Madonna delle Grazie towards Rif. Carmagnola, 2714 m, 0337044 E, 4934652 N (GL-8576 July 2016). Val Maira, Vallone Traversiera, from Madonna delle Grazie towards Rif. Carmagnola, 2345 m, 0337420 E, 4932378 N (GL-8569, July 2016). Val Maira, Vallone Traversiera, from Madonna delle Grazie towards Rif. Carmagnola, 2388 m, 337153 E, 4932635 N (GL-8570 July 2016). Val Maira, Vallone Traversiera from Madonna delle Grazie towards Rif. Carmagnola, pasture, $2365 \mathrm{~m}, 0377252 \mathrm{E}, 4932191 \mathrm{~N}$ (GL-8106, 8108, 810910 luglio 2014). Val Maira. Vallone Traversiera, from Madonna delle Grazie towards Rif. Carmagnola, wall, $2164 \mathrm{~m}, \mathrm{E}, 0338700 \mathrm{E}, 4931253 \mathrm{~N}$ (GL-8118 10 July 2014). Val Maira, Vallone Traversiera from Colle di Traversiera under N. Freide/Aubrage, pasture, $2250 \mathrm{~m}$, NE, 0338596 E, 4930959 N (GL-8189, August 2014). Val Maira, Vallone Traversiera from Madonna delle Grazie towards Rif. Carmagnola, rocks in the pasture, $2363 \mathrm{~m}$, NE, 0337334 E, 4932183 N (GL-8104 10 July 2014). Val Maira, Vallone Traversiera toward Colle di Traversiera under N. Freide/Aubrage, pasture and debris, $2162 \mathrm{~m}$, 
E, 0338729 E, 4931007 N (GL-8205, August 2014). Val Maira, Vallone Traversiera from Madonna delle Grazie towards Rif. Carmagnola, pasture, 2370 m, 0337174 E, 4932257 N (GL-8111, 10 July 2014). Val Maira, Vallone Traversiera from Madonna delle Grazie towards Rif. Carmagnola, pasture, 2365 m, 0337174 E, 4932257 N (GL-8112, 8113, 10 July 2014). Val Maira, Vallone Traversiera towards Colle di Traversiera under N. Freide/ Aubrage, pasture, 2213 m, 0338506 E, 4931356 N (GL8200, 8202, August 2014). Val Maira, Vallone Traversiera from Madonna delle Grazie towards Rif. Carmagnola, rock pasture, $2417 \mathrm{~m}$, E, $0337011 \mathrm{E}, 4932517 \mathrm{~N}$ (GL-8116 10 July 2014). Val Maira, Vallone Unerzio, from Viviere towards Colle Ciarbonet, rocks, 1852 m, E (GL-5274). Val Maira, Vallone Unerzio, from Viviere towards Colle Ciarbonet, wall, 1939 m, (GL-5280). Valle Stura, towards Colle Seroup, pasture with rocks, 2476 m, E, (GL-4938, 4939). Valle Stura, Vallone Arma, from Colle di Valcavera towards Cima di Test, pasture with rocks, $2454 \mathrm{~m}$, SE (GL-4803). Val Stura, Vallone Arma, above S. Giacomo, pasture with rocks, $1735 \mathrm{~m}$, SW (GL-4733). Val Stura, Vallone Arma, above S. Giacomo, debris, $2331 \mathrm{~m}, \mathrm{E}$ (GL4734). Val Stura, Vallone del Piz from Bersello, vallone di Ferrere above Ferrere towards Gias Colombart, pasture, 2189 m, 0335111 E, 4914128 N (GL-8549, 8550). Val Varaita, Vallone Bellino, from Rif. Melezet towards Pian di Traversagn, pasture with rocks, 1998 m, NE, 0697391 E, $4456753 \mathrm{~N}$ (GL-8673). 